\title{
703 FAVORABLE PRE-CLINICAL SAFETY PROFILE OF THE NOVEL NOT-ALPHA IL-2 AGONIST ANV419 SUPPORTS FIRST IN HUMAN CLINICAL DEVELOPMENT
}

${ }^{1}$ Christoph Huber*, ${ }^{2}$ Guzman Alonso, ${ }^{2}$ Elena Gerralda, ${ }^{1}$ Christoph Bucher, ${ }^{3}$ Philippe Jacqmin, ${ }^{1}$ Andreas Katopodis, ${ }^{4}$ Jennifer Sims. 'Anaveon AG, Basel, Switzerland; ${ }^{2}$ Vall d' Hebron Institute of Oncology, Barcelona, Spain; ${ }^{3} \mathrm{MnS}$, Dinant, Belgium; ${ }^{4}$ Integrated Biologix, Basel, Switzerland

Background ANV419 is a novel interleukin-2 (IL-2)/anti-IL-2 fusion protein with preferential signaling through the IL-2 beta/gamma receptor that induces selective proliferation of CD8 T cells and NK cells in vivo for the treatment of cancer. The safety and pharmacodynamic effects of ANV419 were studied in a 4-week cynomolgus monkey GLP study to support the ongoing $\mathrm{PhI}$ dose escalation clinical trial.

Methods ANV419 was administered by i.v. injection over 1 min at doses of $0.03,0.1,0.3 \mathrm{mg} / \mathrm{kg}$, or vehicle control on days 1 and 15 of the 29-day study. Assessments included body weight, blood pressure, hematology, clinical pathology, serum cytokines, immunophenotyping, histopathology, and pharmacokinetics.

Results The pharmacokinetics of ANV419 were characterized by target mediated disposition, with a half-life of approximately $24 \mathrm{~h}$ at concentrations not affected by target mediated clearance. Dose-dependent increases in WBC were observed after each injection, driven by preferential expansion of CD8 $\mathrm{T}$ cells and NK cells over Tregs. NK cells were more sensitive to ANV419 than CD8 T cells reaching maximal proliferation in blood at $0.03 \mathrm{mg} / \mathrm{kg}$ vs. $0.3 \mathrm{mg} / \mathrm{kg}$ for CD8 T cells. Hematological changes included: transient dose-dependent increase in basophils; elevation in eosinophils, up to 2.2-fold above control animals at $>0.03 \mathrm{mg} / \mathrm{kg}$, remaining within the normal range for cynomolgus monkeys $(<1.94 \mathrm{G} / \mathrm{L})$; minor decrease in platelets at day 4 after each injection. There were no relevant treatment-related changes in inflammatory serum cytokines (IL-1b, IL-5, IL-6, IL-8, IFNg, TNFa, GM-CSF). A mild systemic inflammatory response was observed at $0.3 \mathrm{mg} / \mathrm{kg}$ evidenced by a transient increase of CRP on days 4 and 19, preceded after the first injection by a slight dose dependent increase in IL-1RA at $4 \mathrm{~h}$ post injection, and an increase in IL10 at $24 \mathrm{~h}$ post treatment at $0.3 \mathrm{mg} / \mathrm{kg}$. No significant changes in body weights or blood pressure and no signs of capillary leak were observed during the entire study.A multi-part $\mathrm{PhI}$ dose-escalation study of ANV419 has been initiated in cancer patients. In the part A single patient escalation cohort, two patients have been dosed Q2W multiple times with $0.003 \mathrm{mg} /$ $\mathrm{kg}$ and $0.006 \mathrm{mg} / \mathrm{kg}$ respectively with the expected PD profile and no DLT observed.

Conclusions Consistent findings, relating to expected effects of ANV419 as a not-alpha IL-2 agonist, demonstrated a favorable tolerability and safety profile at pharmacodynamically relevant doses that strongly support its translational development in cancer patients to identify clinical benefits.

http://dx.doi.org/10.1136/jitc-2021-SITC2021.703 